Peer review: This article has been subject to a double-blind peer review process

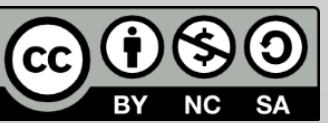

(C) Copyright: The Authors. This article is issued under the terms of the Creative Commons Attribution NonCommercial Share Alike License, which permits use and redistribution of the work provided that the original author and source are credited, the work is not used for commercial purposes and that any derivative works are made available under the same license terms.

\section{One and Many Truths Artistically Acknowledged}

\section{Sara Marzana}

Department of Literature, Film, and Theatre Studies, University of Essex Correspondence: sm16554@essex.ac.uk

\begin{abstract}
Jane Austen's Pride and Prejudice and William Blake's The Marriage of Heaven and Hell both question, criticise and reinterpret the concept of 'truth universally acknowledged'. From the intrinsic relation between the particular and the universal, to the scission between impressions and ideas, Pride and Prejudice concerns some elements of the entire dispute of knowledge. Moreover, The Marriage of Heaven and Hell urges us to reconsider any truth that we recognise as legitimately established, in the attempt to convey that it is our right and duty to determine what we believe-according to our senses, perceptions and feelings. In the eighteenth century, the philosophers of the Enlightenment were indeed disputing the origins of truth and more importantly the ways through which truth is uncovered. In a postmodern world, when, as John D. Caputo remarks, the only universality we acknowledge is diversity, fiction can lead us toward a more profound comprehension of reality - while enriching the flux of our imagination as we perceive the infinite possibilities inherent in human life. This literary approach to the world and its truth prompts us to contemplate existence from a different perspective, to find new meanings presumably hidden beneath the subjectivity of our judgement - to separate specific from universal knowledge. For, even if the prospect of formulating a commonly accepted norm of truth will always endure as humanity's major interest, the real nature of our beliefs is inseparable from our ability to endlessly create, envision and conceive the unrevealed.
\end{abstract}

Keywords: Truth, Friedrich Nietzsche, Jane Austen, Pride and Prejudice, William Blake, The Marriage of Heaven and Hell 


\section{Exploring the Concept of 'Truth Universally Acknowledged' in Pride and Prejudice and The Marriage of Heaven and Hell}

Truth does not exist. According to Friedrich Nietzsche, if we will not accept the truth in the form of tautology - if we will not be satisfied with hollow shells - we will forever exchange truth for mere illusions. The constant drive for truth has been leading mankind since the beginning of time; but it is not yet understood where it comes from. The human intellect seems to have no other aim beyond the preservation of human life. The unawareness of this purpose - which is interpreted by Nietzsche as a lack of purpose - prompts individuals to nurture themselves with illusions, while their gaze can only capture the surface of reality. They become masters at the art of dissimulation. Their intention to be truthful, by adopting generally accepted metaphors, emerges de facto as an obligation to lie in accordance with an established convention - states Nietzsche in his essay On Truth and Lie in an Extra-Moral Sense - written in 1873. Despite their attempt to formulate a universally acknowledged principle of truth, men are constantly immersed in deception. They deceive themselves from dawn to dusk; when they can fall asleep and harbour the sweetest deception of all: the surreal reality of their dreams. While trying to conform to a society that imposes a specific set of rules, individuals are inclined to renounce an essential part of who they are; in exchange for acceptance, recognition and status. Nietzsche writes:

In man this art of dissimulation reaches its peak: among men deception, flattery, lying and cheating, backbiting, posturing, living in borrowed splendour, wearing a mask, hiding convention, play-acting in front of others and oneself, in short, constantly fluttering around the single flame of vanity, is so much the rule and law that there is hardly anything more incomprehensible than how an honest and pure drive for truth could have arisen among them (Nietzsche, 2009: 254).

This infinite search for truth could thus be a representation of an endless need to find a motive to the uncertainty of life - a plausible sense in our much to do about nothing - rather than an actual quest for the principle itself. It may symbolise the effort to apply logic to something dramatically absurd, overly distressing to accept. Nevertheless, truth is intrinsically related to ethics, to practical and theoretical values without which humanity cannot survive and most all cannot progress. Hence, the road to this principle - despite being exceedingly difficult and intricate - will always be crossed. 
Our knowledge of the world that assures us that some of the things we are aware of are true: we are in a building with doors and windows, we make conversation with people like ourselves - the sun is going to rise tomorrow. It is exactly through these assumptions of what is true and what is not, that our mind relates with the external reality, notes Simon Blackburn (Blackburn, 1999: 3). However, this external reality has been logically constructed by mankind in the attempt to make it determinable, coherent and explainable. According to Nietzsche, for this reason, it must be deemed as another 'piece of fiction' (Nietzsche, 1910: 36). If we assume that the world as we know it consists in the most logical interpretation that humanity has found to acknowledge it, the fictional interpretation of reality can represent another approach to the world and its truth. Even if it is only a representation of life, the literary work enables the individual to look at existence with different eyes, to reflect on the meaning of experience from a new perspective. In a literary text, the truth is decidedly contextualised - remarks Vittorio Hösle - for the story is written in a specific time and culture, with a certain intention, or a set of intentions and it is usually characterised by semantic, realistic and aesthetic purposes by its author (Hösle, 2017: 227). Nevertheless, readers of all times have had and continue to have the chance to comprehend their surrounding environment and themselves through the pages of a novel, the lines of a poem, or the acts of a play. This constitutes the inner potential of the written matter, both fictional and non-fictional.

Jane Austen's Pride and Prejudice, published in 1813, and William Blake's The Marriage of Heaven and Hell, composed between 1790 and 1793, both offer illuminating and endlessly relevant views on the question of truth. The opening line of Pride and Prejudice states: 'It is a truth universally acknowledged that a single man in possession of a good fortune must be in want of a wife' (Austen, 1956: 5). The ironic tone of this assertion constitutes a purposeful guide to the entire novel, notes lan Littlewood (Littlewood, 1993: 3). In Pride and Prejudice, the truth - or something like the truth - is not revealed by what the narrator announces or by what the characters say - it is depicted by the events that occur in the story. While Austen warns us about the importance of mistrusting any rushed assumption, she offers us insights into the real without seeking to reveal any truth. It is the very idea that truth cannot be found at all, that our judgements rely on the most subjective premises, and that the right interpretation could eventually emerge as a tragic misreading that characterises Austen's novel. According to Felicia Bonaparte, in her lucid approach to the fleeting nature of reality, Austen anticipates problems that will later become central to both modernism and postmodernism. 
The narrative is thus a quest for an epistemological principle on which a suitable hypothesis of reality can rest. And while there is never any question that we are looking at a work rooted in its time and place, in the process of this quest Austen foreshadows many issues central to modernism and postmodernism, even to current critical theory-all rooted, if we look back far enough, in that very empiricism Austen was one of the first to embrace (Bonaparte, 2005: 143).

The constitution of the chronotope in Pride and Prejudice is highly dependent on the temporal dimension, which allows the characters to evolve while becoming crucial to their understanding of the essence of things, and to the making of their most important decisions. Time is thus significant to the unfolding of reality, which is never thoroughly unfolded. The story, told by a third person omniscient narrator, revolves around the author's major theme: the disposition of young women in marriage; where the significance of this legal union is given by the assurance of a status, notes Littlewood (Littlewood, 1993: vii). The singular path that will bring Elizabeth and Mr. Darcy together for life becomes a universal recognition of the absence of logic characterising human behaviour, a declaration of how the simple act of changing one's mind could lead to a remarkable personal growth: 'And I had not known you a month before I felt that you were the last man in the world whom I could ever be prevailed on to marry', says Elizabeth (Austen, 1956: 188).

When reading Pride and Prejudice, Claudia Brodsky Lacour observes, it is natural to accept several concepts as already established; because the writer has remarkably outlined that fiction, like history, relies only in the representation of the particular. The relation between this particular and the universal truth is absolutely arguable and inevitable - it cannot be taken for granted - which is something that people often forget or ignore. The story line of the book fulfils the author's aim of validating that universal truth by presenting it to the flow of experience - to turn it into the history of a notion that its first sentence originally declares. The essential significance of the opening is not related to the view about marriage that it sets out, but to the life, the personal behaviour and the involvement of those who genuinely believe in it. 'The first persons to be represented in this novel, or rather, to represent themselves in their own words, are cogent arguments against the truth that the novel proposes' (Lacour, 1992: 612). The marriage between Mr. and Mrs. Bennet is portrayed as a long-lasting devotional divorce - an accomplished dissolution of opposite beings. Even though it cannot be entirely deemed as an argument against the opening of the novel, this matrimony is a declaration that what is universally considered a well-known truth - a rich man must desire to marry an admirable woman - might turn into a permanent error. The truth that Pride and Prejudice legitimises at the end 
of novel as story, is that it is important to separate specific from universal knowledge - writes Lacour - opinion from pride and from prejudice (ibid: 609-619). Austen does not deny the responsibility implicated in the depiction of her ideas in the text, although it is noticeable from the beginning that her reflections are probably going to suggest an ironic affinity to the characters' views.

One of the key passages of the narrative is represented by Elizabeth's reading of Darcy's letter. In the attempt to understand the nature of his intentions - as well as the essence of Darcy's character - Elizabeth is caught in a whirl of emotions. She reads it not only once, but twice; for her confused state of mind is preventing her from seeing things clearly. 'She read, with an eagerness which hardly left her power of comprehension, and from impatience of knowing what the next sentence might bring, was incapable of attending to the sense of the one before her eyes' (Austen, 1956: 198). Still, Elizabeth is determined to uncover the truth. Even though Austen is highly philosophical - attentive both to concepts in general and to the philosophical debate of her time - she hardly expresses these theoretically, argues Bonaparte. 'Mostly her conceptual world is so fully dramatized in her characters and her plots that it can only be inferred from the nature of the action and the language of the narrative' (Bonaparte, 2005: 142). In Pride and Prejudice, the epistemological questions concerning the existence of truth (whether it can be known, its meaning, and the degree of certainty of its meaning) are central to the novel. Austen uses several lexical devices such as 'guess', 'perceive', 'construe', 'presume', 'believe', 'suspect', to advise readers on the indeterminateness of the words lying in front of them. It is rare to find a character asserting 'I know', without being proved wrong (ibid: 142). When Lady Catherine arrives to the Bennet's house, deeply outraged, looking for an explanation of the rumour of his nephew marrying Elizabeth, she knows that it must be a falsehood.

A report of a most alarming nature, reached me two days ago. I was told, that not only your sister was on the point of being most advantageously married, but that you, that Miss Elizabeth Bennet, would, in all likelihood, be soon afterwards united to my nephew, my own nephew, Mr. Darcy. Though I know it must be a scandalous falsehood [...] (Austen, 1996: 198).

On the other hand, the phrase 'I know not' - indicating how little the characters know of the world around them, appears numerous times in the novel. Austen, states Bonaparte, openly distrust the idea that human knowledge can ever be certain and definite. Her modernism consists in her recognition that her characters' thoughts, feelings, decisions and actions are deeply immersed and significantly influenced by the temporal context. 
Just as in life, we are only able to grasp the essence of a moment after its passing. In Pride and Prejudice, every realization ultimately leading to a definitive choice, is determined by the passage of time - along with the drastic changes that it brings into being.

Austen is suggesting that there is always time to change one's mind - to observe the world from a unique point of view: a more cultivated, better structured and conscientious perspective. To this end, fiction is a neverending collection of insights into the real. While consciously representing reality, it uncovers truths without ever presenting them as such. In Pride and Prejudice, among all the characters, Elizabeth is the only one that will learn - as she learns to read Darcy's letter - how the read the world. According to Bonaparte, the development of this skill is the bildung of the novel, and what Elizabeth develops throughout the story is a practical empiricism. Her 'quickness of observation' (Austen, 1956: 17) is the first quality attributed to her, which is the principal characteristic of an empiricist. The development of this character is primarily philosophic, and each one of Elizabeth's recognitions leads to this end. In the course of her learning the protagonist will realise that everything supposed to be rational may also be deceitful. This is how Austen shows the defects of rationalism, while indicating that even empiricism cannot convey how things are - it can only contemplate how they appear (Bonaparte, 2005: 145-148). Hence, the characters in the novel are always mentioned by their 'appearance', rather than by their 'presence'. Bingley, for instance, 'was sure of being liked whenever he appeared' (Austen, 1956: 18). Elizabeth and Mr. Collins met for breakfast 'a few minutes before the others appeared' (ibid: 208). Elizabeth herself affirms: 'The more I see the world, the more I am dissatisfied with it; and every day confirms my belief of the inconsistency of all human characters and of the little dependence that can be placed on the appearance of merit and sense' (ibid: 133). Austen, while demonstrating her awareness of the void between perception and reality, is further suggesting that we can never really know what is front of our eyes; we can only rely on its fleeting impression.

The initial title of Pride and Prejudice was First Impressions, as Jasmine Gooneratne points out - a great concern of David Hume's philosophy reported in his Treatise of Human Nature. In this essay - written in 1738 Hume identifies pre-eminence as the origin of our knowledge. He affirms that in order to comprehend our opinions we ought to return to our impressions (Gooneratne, 1970: 106-08). According to the philosopher, all the perceptions of the human mind are divided in two specific types: impressions and ideas. The ones that insinuate strongly in our conscience are defined as impressions - they include all sensations, passions and feelings - whereas the impressions that are modified through our thinking and reasoning are identified as ideas. These are furthermore divided into 
simple and complex (Hume, 2009: 16-18). Given that Elizabeth has an active mind, her impressions and her ideas are of the second kind; but why are 'first impressions' so important? (Gooneratne, 1970: 109). As Hume suggests, because they embody the beginning of our experience: without impressions there is no experience, and without experience there is no reasoning. Hume states: 'Since it appears, that our simple impressions are prior to their correspondent ideas, and that the exceptions are very rare, method seems to require we should examine our impressions, before we consider our ideas' (Hume, 2009: 26). The human being should therefore be somebody who experiences reality as well as somebody who thinks and reasons about reality - this is what we learn from Hume and Austen, states Gooneratne (Gooneratne, 1970: 110). From the renowned and provocative pronouncement that opens Pride and Prejudice to the rest of the story, we can find perpetual reminders of the fluctuating nature of people's truth; for what is 'universally acknowledged' can modify not only according to the changes of society, but also from person to person and within the person's mind from time to time. Austen emphasises how precarious and miscellaneous are people's judgements, ideas and interpretations of any circumstance they find themselves involved in: '"But people themselves alter so much, that there is something new to be observed in them forever"' (Austen, 1956: 43), says Elizabeth.

When the protagonist meets Darcy, she's utterly convinced that he is 'the proudest, most disagreeable man in the world' (ibid: 13) - while by the end of the novel he becomes her loving husband. She is convinced of Darcy's unfavourable disposition and enjoys the company of Mr. Wickham who is provisionally liked by everyone. In the novel, just as in life, people's opinions of whoever is around them are strictly connected to the fact that other people's behaviours emerge each time in a new and different light. For instance, Elizabeth's sister, Jane, is the only one that does not judge malevolently Darcy when all the others are submitted to their first impression of him. Elizabeth criticises Darcy in an extremely short period of time, while the proof upon which she builds her judgement is too little. Later on, as the perceptions and ideas change, Mr. Wickham becomes 'the wickedest young man in the world' (Austen, 1956: 280). Similarly, the reputation of the Bennet's family alters completely over a few weeks: 'The Bennets were speedily pronounced to be the luckiest family in the world, though only a few weeks before, when Lydia had first run away, they had been generally proved to be marked out for misfortune' (Ibid: 331). This process of recognition is universal and well established in the literary world:

There is much in our literature as well as our experience to suggest that the person who never comes to the point of saying 'I never knew myself', will indeed remain for ever cut off from any self-knowledge - 
what possible effect there is on his or her vision and conduct need not here be spelt out. If we don't know ourselves, we don't know our world (Gooneratne, 1970: 113).

Austen's greatest accomplishment is to reveal us through the story something about ourselves: we often forget to question our deepest beliefs, we run into conclusions when it is too soon to judge, and we minimise that the positions we take in life create the real source of our happiness. This is the power of narrative, to make people aware of feelings and behaviours that they do not identify, to prompt them to discover a new meaning that is not hidden between their deepest doubts. Andrew $\mathrm{H}$. Wright observes:

Fiction has an advantage over life in being more completely revealing: truer, as poetry is truer than history. In the novel, we see people's thoughts and imaginings without the colorations of fear, reserve and diffidence, which in life constitute effective barriers against the disclosure of personality (Wright, 1954: 76).

The greatest gift that Elizabeth receives, writes Gooneratne, is to genuinely realise that there is an enormous difference between essence and appearance (Gooneratne, 1970: 114). With its own interpretation of reality fiction does not aim at depicting a singular, predominant truth. This premise, lying behind any remarkable fictional work, is what makes literature an interminable source of truthfulness, from which we can all learn to deepen our understanding of life and the meaning of our own experience. For - as Erich Auerbach states - in Mimesis:

(...) there is always going on within us a process of formulation and interpretation whose subject matter is our own self. We are constantly endeavouring to give meaning and order to our lives in the past, the present, and the future, to our surroundings, the world in which we live; with the result that our lives appear in our own conception as total entities - which to be sure are always changing, more or less radically, more or less rapidly, depending on the extent to which we are obliged, inclined, and able to assimilate the onrush of new experience (Auerbach, 2003: 549).

Austen's epistemological language demonstrates that she knows that the right picture, if there is one, is beyond our reach, and that different pictures are possible, while the ones we create in our minds rest on the patterns we make of our data, as Bonaparte remarks (Bonaparte, 2005: 149). If it is possible to uncover reality after unveiling our first impressions - which could always be shaped by prejudice, it becomes crucial to cautiously analyse the presumably convincing evidence that has been provided before the actual evaluation takes place. 
In this novel Austen also radically reject the concept of authority; the idea that there are some truths that we inherit from our ancestors, from the past, from religion. She consistently criticises every conventional social standing, parental figure and representative of the clergy as the main embodiments of authority. As Bonaparte points out, the majority of those who claim authority or on whose behalf it is claimed are derided. Even when the former does not appear as an object of derision, it is still not possible to depend on its truth, Austen proves (ibid: 146). The author's reflection on the implications of the words 'truth' and 'universal', suggests Gooneratne, has been prompt by the eighteenth-century discussion on knowledge, and what John Locke indicated as 'the discerning faculties of man' (Gooneratne, 1970: 105). It entails studying not merely the problem of what we know, but also the query of how we know what we know, as well as analysing the restraints set on knowledge by the procedures and means of cognition. In his Essay Concerning Human Understanding - first appeared in 1689 - Locke states:

On this faculty of distinguishing one thing from another depends the evidence and certainty of several, even very general, propositions, which have passed for innate truths; - because men, overlooking the true cause why those propositions find universal assent, impute it wholly to native uniform impressions; whereas it in truth depends upon this clear discerning faculty of the mind, whereby it perceives two ideas to be the same, or different (Locke, 2000: 117).

Locke believed that it is essential to discover and establish the limits between opinion and knowledge. He believed in the urge to distinguish as Nietzsche will define it - a long-lasting metaphor turned into a fixed and binding truth, while recognising to what extent it could completely revolutionise our thought. In Pride and Prejudice, Mary is the emblem of this issue: the opinions she expresses in the text are not wrong in themselves, but they are postulated a priori, without ever being questioned or verified, as Bonaparte points out (Bonaparte, 2005: 147). When she comments on pride - and how it affects people - Mary does not rely on her own past experience, or her own power of observation; she reaches a banal conclusion based on everything she consulted on the subject.

"Pride," observed Mary, who picked herself upon the solidity of her reflections, "is a very common failing I believe. By all that I have ever read, I am convinced that it is very common indeed, that human nature is particularly prone to it, and that there are very few of us who do not cherish a feeling of self-complacency on the score of some quality or other, real or imaginary. Vanity and pride are very different things, though the words are often used synonymously. A person might be 
proud without being vain. Pride relates more to our opinion of ourselves, vanity to what we would have others think of us" (Austen, 1996: 21).

According to Mary, the notions provided by her readings are a source of knowledge to be accepted with no further inquiry, becoming a form of authority on her considerations regarding pride. While letting the events of the story speak for themselves, Austen proves that general truths are merely empty clichés, lacking any substantial meaning - as they are always with Mary. Tradition might be wise or not, but the only way to recognise it is to test it ourselves (Bonaparte, 2005: 145).

The radical unwillingness to conform to the patterns already established by society is a position that Austen, Blake and Nietzsche felt very comfortable in. Their rejection to settle for what is universally acknowledged and their openness to the unlimited interpretations of reality makes their work significantly relevant to the search for truth. From Locke's philosophy, notes Gooneratne (1970: 140), Blake took the word 'horizon' and turned it into 'Urizen', a symbolic figure that represents every limited and self-restrained man. Urizen's character is entrapped by the net that he spun with his own assumptions. His fate appears to depend on his capacity to point with both hands at the same time while concurrently revealing and parodying his own theories, affirms Stephen D. Cox (1992: 16). Blake, who did not agree with Locke's rational view of human nature, chose to delight himself with his visions and his wide imagination - instead of conforming to the norm and adhering to the limits imposed by the society of his time. Blake affirms: 'Energy is the only life and is from the Body and Reason is the bound or outward circumference of Energy. Energy is Eternal Delight' (Blake, 2011: 63). According to the poet we are composed by opposite forces in never-ending conflict; reason is right, but merely in its role of containing the energy of an individual. Both Blake and Nietzsche, while reacting against the fierce success of Western civilization, questioned on the one side its conventions and beliefs and on the other its notions about intelligible thinking and representation of existence, states Harvey Birenbaum in his study Between Blake and Nietzsche. They both engaged in what Nietzsche called 'the revaluation of all values', both prompt by a will to reconceive the nature of human reality (Birenbaum, 1992: 4). 'This meant the energetic exploration of the nonrational and the affirmation of life in a spirit free of the mind's usual, familiar and secure habits of logic' (ibid: 4).

The Marriage of Heaven and Hell is a structurally and ideologically subversive text that, according to Steve Vine, eagerly intervenes in the energies of political uprising that unsettled Europe with the beginning of the French Revolution in 1789. In Blake's depiction of the religious mind- 
set the Priests are the 'Angels' of morality - citizens of 'Heaven' - while the artists are the 'Devils' of dissension, imagination, revolt and insurrection: citizens of 'Hell'. His radical project in the Marriage is to renew the importance of thinking 'from impulse. not from rules' (Blake, 2011: 82), affirming that it is the unstoppable and diabolic source of imaginary vision that nourishes the 'fires' (ibid: 61) and 'enjoyment of Genius' (ibid: 65). The proverbs presented by Blake in the central section of the text, entitled 'Proverbs of Hell', are in fact anti-proverbs, or parodies of proverbs that ridicule the main principle of proverbial, generalizing, conventional wisdom (Vine, 2007: 40-43). The most revealing line of the section is: 'Truth can never be told as to be understood, and not be believ'd' (Blake, 2011: 69). It openly clashes with the essential meaning of a proverb, which is to convey a basic truth. Blake does not believe in the possibility that truth can be expressed in a way that imparts actual understanding, much less wisdom. Truth can only be envisioned; in an act of vivacious linguistic freedom from all the constraints of tradition, society and thought. He considers both science and theology as threatening menaces to the free and unrestrained evolution of the self. The truth of his work lies in its potentially inexhaustible capacity to uncover its errors and restraints, writes D. Cox. Blake does not believe that truth exists objectively. As it appears, the one objective truth is the idea that there is no objective truth (Cox, 1992: 4). Nonetheless, even readers most influenced by a priori conviction of the ironic tone characterising Blake's aphorisms 'are expected to grow increasingly hard-pressed to imagine how his text could possibly have been generated by anything less than an obsession with truth, unqualified and authoritative truth' (ibid: 5), argues Cox. His provocative, disturbing, ironic statements cannot be rationalised in any scheme, principle or system; they can rather be interpreted as embodiment of the whole miscellaneous and unsystematic style of The Marriage itself, which constitutes a heterogeneous ensemble of linguistic forms - none of which is predominant on the others but all of which participate to the dialectic carnival of the text (Vine, 2007: 43). 'The Marriage is a radical verbal democracy, a theatre of symbolic or formal 'revolution' in which hierarchies and authorities are dethroned in a celebration of multiplicity, contrariety, contest' (ibid: 43), states Vine.

To create, for Blake, is to feel with the utmost intensity the flow of life and while deeply immersed in this sentiment, to fill the blank page with something imaginatively significant. It entails perceiving with sympathy, understanding the truth about existence by conceiving states of mind - by recognising them in ourselves, writes Birenbaum. In this sense, the language and the experience of life are inseparable, particularly when at the heart of the matter lies the question of truth and how to express it. The main word 'truth' communicates different meanings: it can signify the 
knowledge of reality, reality itself, or the emphasis on a given notion of truth. These are not different opinions on the matter, but merely three uses of the word labelling three different concepts (Birenbaum, 1992: 97109). For this reason, Blake, an intellectual who believed unconditionally in the power of imagination, did not want to be entrapped in a vocabulary that would influence and direct the thought. He radically refused to accept linguistic conventions as the most adequate mirror to reflect moments of the real. This is a view that Blake and Nietzsche shared with the utmost artistic and philosophical fervour. 'Is language the adequate expression of all realities?' asks Nietzsche (2009: 255). ' 'If the doors of perception were cleansed every thing would appear to man as it is, infinite', suggests Blake (2011: 73). They both strongly believe that, as Birenbaum puts it, language sets its limitations on thinking, which sets its limitations on the comprehension of our experience. It is indeed by narrating our experiences in terms that our peers can understand - and therefore accept - that we deprive them of their unique essence (Birenbaum, 1992: 113114). Our own distinctive experience becomes another universally familiar diapositive in the human collection of memories, because to make it understandable, recognisable to others - in other words to simplify it - we lessened its unique value. It is perhaps for this motive, that Blake rose up against a particular type of rationalism, which used words such as 'memory' and 'abstraction' with a significance he did not approve, for he consider it a materialistic terminology, notes Hazard Adams (1954: 234). Words are, for Blake and Nietzsche, mainly 'opportunities to play meanings on - and the meanings are metaphors', suggests Birenbaum (1992: 80).

Literature is the boundless playground for this occupation - it allows words to infinitively connect on the page, creating each time a different meaning and multiple meanings at once. It opens the doors to reality while never attempting to enclose it in a specific frame - allowing us to grasp one and many truths, without them being truths themselves. In its vivid repertoire of life-like representations, fiction produces meaning by its interaction with the reader's imagination. The purity of truth relies only in the mental image - Blake believes - which is not merely seen by the artist, but by all individuals - for the imagination gives them the opportunity to transcend nature. 'Every thing possible to be believ'd is an image of truth' (Blake, 2011: 67). Forasmuch as every single person can envision, create and profess its own truth, the idea of a universal conception of truth seems unattainable - because human knowledge can hardly transcend the limits of perspective. It is by asserting that all knowledge is particular that Blake clearly anticipates Nietzsche's perspectivism. In The Will to Power, Nietzsche will argue: 'To the extent to which knowledge has any sense at all, the world is knowable: but it may 
be interpreted differently, it has not one sense behind it, but hundreds of senses. - 'Perspectivity" (Nietzsche, 1910: 13)." A century later, the philosopher will continue the path undertaken by the poet in his attempt to free the thought from every restraint preventing it from being the most imaginatively truthful it can possibly be. Besides being an ironic attack to the authoritarian and dogmatic approach of religion and to a society that stands on its own hypocrisy, The Marriage of Heaven and Hell invites us to reconsider any truth deemed as universally acknowledged in a conscious effort to evaluate reality within our own perceptions and feelings, to independently conceive our own beliefs, notes Stephen C. Behrendt (1992: 94-100).

Nevertheless, what happens if everybody starts to believe a different truth? Could we ever find be a generally accepted principle of this matter? Yes, according to Blake - the commencement of this journey towards a 'central form' consists in the urge for each individual to come to terms with the deceptive nature of substance, language, projection, and every other deceit of reality. Only through art there is a revelation of truth - the model of human life. In this sense Blake considers his work prophetic, states Adams (Adams, 1954: 243-48). However, the real issue with The Marriage is succeeding in the subtle art of finding the poet's authentic voice among the ever-present irony and provocative tone of the page. To this regard, with his theory of contraries, stated in his renowned passage - 'Without Contraries is no progression. Attraction and Repulsion, Reason and Energy, Love and Hate, are necessary to Human existence' (Miller, 1985: 505) ) $^{\mathrm{ii}}$ Blake seems to convey that the very possibility of expressing truth is negated unless it is represented in an opposition of terms, suggests Dan Miller (ibid). Interestingly, Birenbaum remarks that both Nietzsche and Blake write not only with the anger of men whose voice cannot be heard, but also with the knowledge that they cannot speak their truth without contradicting themselves (Birenbaum, 1992: 87). Furthermore, centuries ago, Plato argued that truth cannot be permanently declared in a methodical or phrasal form; while Aristotle affirmed that our fundamental principles are not observable in their totality, but merely in a constant association and confrontation with one another. While the philosophical debate continues, and knowledge formidably advances, the human intellect becomes increasingly aware of how difficult and complex is the path towards truth. The only certainty seems to be the fact that there is no certainty. Hence, the sole possible way of conceiving truth is to accept the idea that it cannot be permanent, steady or universally established. It is rather variable, erratic and always questionable. Indeed, Blake's complete body of work is indeterminate, writes Cox, because he seeks to keep his meanings from becoming so (Cox, 1992: 23). 
In a postmodern world, when, as John D. Caputo points out - 'our first thought is that everyone's truth is entitled to its fifteen minutes in the sun' (Caputo, 2013: 9) - recognising what 'truth' means becomes even more crucial. To this end, it is the dedication and eagerness to create, that will continue to guide mankind in its philosophical quest, as Frederick Sontag remarks, and Blake should be our allied and teacher in this sense. He understood that the infinity of the imaginable worlds, which we are able to encounter through our creative thought, are unbelievably more imminent to us than we can possibly imagine (Sontag, 1998: 57-63). While the potential of narrative prompts us to acknowledge truths regarding the unlimited possibilities intrinsic in human life, our task is to allow its suggestions to enrich the flux of our imagination and lead us to a more profound comprehension of reality. By all means, fiction can support us in our attempt to confront what we fail to understand, it can prompt us to reconsider what is not yet conclusively proved; while granting us a chance to revaluate not only our truths, but also ourselves.

\section{References}

Adams, Hazard. 1954. 'The Blakean Aesthetic'. The Journal of Aesthetics and Art Criticism, 13 no. 2, 233-248. doi:10.2307/425916.

Auerbach, Erich. 2003. Mimesis: the Representation of Reality in Western Literature. Princeton, N. J.: Princeton University Press.

Austen, Jane. 1993. Pride and Prejudice. Ware: Wordsworth Editions.

Austen, Jane. 1996. Pride and Prejudice. London: Penguin.

Behrendt, Stephen C. 1992. Reading William Blake. Basingstoke: Macmillan.

Birenbaum, H. 1992. Between Blake and Nietzsche: the Reality of Culture. Lewisburg, Pa: Bucknell University Press.

Blackburn, Simon, and Simmons Keith. 1999. Truth. Oxford: Oxford University.

Blake, William. 2011. The Marriage of Heaven and Hell. Oxford: The Bodleian Library.

Bonaparte, F. 2005. 'Conjecturing possibilities: Reading and Misreading Texts in Jane Austen's "Pride and Prejudice"'. Studies in The Novel, 37 no. 2, 141-161. http://www.jstor.org/stable/29533681.

Brodsky Lacour, Claudia. 1992. 'Austen's Pride and Prejudice and Hegel's "Truth in Art": Concept, Reference, and History'. ELH, 59 no. 3, 597-23. http://www.jstor.org/stable/2873444. 
Caputo, John D. 2013. Truth: Philosophy in Transit. London: Penguin Books.

Cox, Stephen D. 1992. Love and Logic: the Evolution of Blake's Thought. Ann Arbor: University of Michigan Press.

Gooneratne, Yasmine. 1970. Jane Austen. Cambridge: University Press.

Hösle, Vittorio. 2017. Forms of Truth and the Unity of Knowledge. Notre Dame: University of Notre Dame Press.

Hume, David. 2009. Treatise of Human Nature: Being an Attempt to Introduce the Experimental Method of Reasoning into Moral Subjects. Auckland: The Floating Press. ProQuest Ebrary.

Lacour, C. B. 1992. 'Austen's Pride and Prejudice and Hegel's "Truth in Art": Concept, Reference, and History'. ELH, 59 (3), 612.

Littlewood, I. 1993. Introduction to Pride and Prejudice. Ware:

Wordsworth Editions.

Locke, John. 2000. An Essay Concerning Human Understanding. Ontario: Batoche Books, ProQuest Ebrary.

Miller, Dan. 1985. 'Contrary Revelation: "The Marriage of Heaven and Hell'. Studies in Romanticism, 24 no. 41, 491-509.

http://www.jstor.org/stable/25600563.

Nietzsche, Friedrich. 1910. The Complete Works of Friedrich Nietzsche, Edinburgh and London: T. N. Foulis.

Nietzsche, Friedrich. 2009. Nietzsche: Writings from the Early Notebooks. Cambridge: Cambridge University Press.

Sontag, Frederick. 1998. Truth and Imagination: The Universe Within. Lanham, MD: University Press of America.

Vine, Steve. 2007. William Blake, Tavistock, Devon: Northcote House Publisher.

Wright, Andrew. 1953. Jane Austen's Novels; A Study in Structure. New York: Oxford University Press.

To cite this article:

Marzana, S., (2018). One and Many Truths Artistically Acknowledged.

Exchanges: The Interdisciplinary Research Journal, 5(2), 90-105. Retrieved from:

http://exchanges.warwick.ac.uk/index.php/exchanges/article/view/234 


\footnotetext{
' Nietzsche, Nietzsche: Writings from the Early Notebooks, 255.

ii Nietzsche, The Will to Power, 13.

iii Blake, The Marriage of Heaven and Hell, 62.
} 